\title{
Communication \\ Performance of Silica Fume-Based Geopolymer Grouts for Heritage Masonry Consolidation
}

\author{
Luis G. Baltazar (DD
}

check for updates

Citation: Baltazar, L.G. Performance of Silica Fume-Based Geopolymer Grouts for Heritage Masonry Consolidation. Crystals 2022, 12, 288. https://doi.org/10.3390/ cryst12020288

Academic Editor: Jesús SanmartínMatalobos

Received: 5 February 2022

Accepted: 16 February 2022

Published: 18 February 2022

Publisher's Note: MDPI stays neutral with regard to jurisdictional claims in published maps and institutional affiliations.

Copyright: (c) 2022 by the author. Licensee MDPI, Basel, Switzerland. This article is an open access article distributed under the terms and conditions of the Creative Commons Attribution (CC BY) license (https:/ / creativecommons.org/licenses/by/ $4.0 /)$.
Department of Civil Engineering, NOVA School of Science and Technology, FCT NOVA, 2829-516 Caparica, Portugal; luis.baltazar@fct.unl.pt; Tel.: +351-212-948-300

\begin{abstract}
Despite the increasing number of studies on geopolymer-based materials, a lack of information still prevails concerning the use of geopolymer materials for the consolidation and conservation of the built heritage. Since the introduction of the term "geopolymer" by Davidovits, several studies have pointed out geopolymers as a potential replacement for traditional binders, mainly due to their advantages associated with mechanical properties and low carbon dioxide emissions. The geopolymers (also known as alkali-activated materials or inorganic polymers) are obtained by a chemical process through which precursors rich in silica and alumina interact with an alkaline medium to result in a material with binding properties. The aim of this study is to exploit the potential of geopolymer-based grouts in the consolidation of stone masonry buildings. Grouting or grout injection is a technique used for the consolidation of heritage masonry buildings; it consists of the introduction of a binding agent to fill the internal voids and cracks. An experimental program was carried out to improve knowledge of geopolymer grouts suitable for consolidation purposes. The experimental findings revealed that the silica-fume-based geopolymer grout has a worse performance from a rheological point of view, whereas it showed promising results in terms of mechanical strength when compared to traditional hydraulic-lime-based grout.
\end{abstract}

Keywords: geopolymer; grout; silica fume; masonry; consolidation; rheology; mechanical strength

\section{Introduction}

Traditional binder materials such as Portland cement and lime are among those with the greatest environmental impact because they represent approximately 2.6 billion tons per year of greenhouse emissions and also contribute to significant consumption of natural resources [1,2]. In this scenario, the European Union has defined a strict policy on climate action [3] and, at the same time, several studies [4,5] have presented alternatives to traditional binders such as geopolymers that are environmentally sustainable and with properties equivalent to or better than those of cement-based materials. Nevertheless, in the field of conservation of the built heritage, a lack of information still prevails concerning the use of geopolymer materials for the consolidation and conservation of the built heritage [6,7].

In the 1970s, Davidovits proposed a new and alternative binder, called geopolymer, based on the chemical reaction between raw materials and alkaline activator [8]. Raw materials should be based on alumina-silicate; they could be byproducts like fly-ash, silica fume, slag, etc. The alkaline activators that are often used in geopolymer production are $\mathrm{NaOH}-$ or $\mathrm{KOH}-b a s e d$ [9]. Concerning the use of alkaline activators, Ryu et al. [10] have observed that higher concentration of activators better promotes the geopolymerization process. This geopolymerization involves formation of a three-dimensional polymeric chain by the Si-Al mineral to form a structure which consists of Si-O-Al or Si-O-Si bonds. There are other variables that influence the geopolymerization process and, therefore, the performance of geopolymers, such as type of curing, curing temperature, surface area of solid materials, type of materials containing aluminosilicate, electrostatic forces, and curing time, among 
others [11-13]. This inorganic binder can be considered as an alternative material for conservation of the built heritage considering its durability, mechanical strength, and aesthetic compatibility with the heritage materials, which is seen as another advantage $[14,15]$.

However, a very limited amount of work has been reported on the potential of geopolymers for grouting of old stone masonry walls [16]. Grouting or grout injection is a technique used to intervene in historic masonry buildings; it consists of the introduction of a binding agent to fill the internal voids and cracks $[17,18]$. In this work, preliminary results of geopolymer grouts made with a solution of sodium hydroxide-sodium silicate as activator and silica fume as raw material were compared with traditional natural hydraulic-limebased grouts. Grouts with different fluidity and mechanical strength were obtained by varying the concentration of the alkaline solution and superplasticizer dosage. The Marsh cone and mini-slump values, flexural and compressive strength, adhesion strength, open porosity, and hardened density were measured and compared.

\section{Experimental Work}

\subsection{Materials}

\subsubsection{Silica Fume}

Silica fume (SF) is a byproduct in the production of ferrosilicon industry and it is often used as a cement replacer to improve the performance of cementitious materials. The SF was provided by Mapei (Portugal) and was used in a non-densified state. Its bulk density and specific surface area are $2.2 \mathrm{~g} / \mathrm{cm}^{3}$ and $17.5 \mathrm{~m}^{2} / \mathrm{g}$, respectively. The particle size was found to be between 2 and $30 \mu \mathrm{m}$ (with $80 \%$ below $10 \mu \mathrm{m}$ ) and the chemical properties are listed in Table 1.

Table 1. Chemical properties of NHL and SF.

\begin{tabular}{ccc}
\hline Component & SF & NHL \\
\hline $\mathrm{Al}_{2} \mathrm{O}_{3}$ & $0.15 \%$ & $2.00 \%$ \\
$\mathrm{CaO}$ & $0.20 \%$ & $85.00 \%$ \\
$\mathrm{Fe}_{2} \mathrm{O}_{3}$ & $0.03 \%$ & $2.00 \%$ \\
$\mathrm{MgO}$ & $0.30 \%$ & $1.00 \%$ \\
$\mathrm{MnO}$ & & $0.03 \%$ \\
$\mathrm{SiO}_{2}$ & $97.00 \%$ & $8.00 \%$ \\
$\mathrm{SiC}$ & $0.50 \%$ & $0.01 \%$ \\
$\mathrm{SO}_{3}$ & & $1.00 \%$ \\
$\mathrm{SrO}$ & & $0.05 \%$ \\
$\mathrm{~K}_{2} \mathrm{O}$ & $0.80 \%$ & $0.70 \%$ \\
$\mathrm{Na}_{2} \mathrm{O}$ & $0.05 \%$ & \\
\hline
\end{tabular}

\subsubsection{Natural Hydraulic Lime}

The natural hydraulic lime (NHL) used in this study was produced in Portugal according to EN459-1:2010 [19], which are the chemical properties shown in Table 1. The NHL was used in the formulation of the reference grout (Ref) and is the ideal binder for masonry consolidation operations as it is the hydraulic binder with the best compatibility with the original materials of the old masonries.

\subsubsection{Alkaline Activator}

It was established that a combination of sodium hydroxide $(\mathrm{NaOH})$ and sodium silicate $\left(\mathrm{Na}_{2} \mathrm{SiO}_{3}\right)$ offers better mechanical performance to geopolymers [20]. Thus, the alkaline solution of $\mathrm{NaOH}$ and $\mathrm{Na}_{2} \mathrm{SiO}_{3}$ was adopted in this study (Figure 1). A solution with a molar concentration of $12 \mathrm{M}$ of $\mathrm{NaOH}$ was prepared and due to its exothermic reaction, the solution was prepared one day before casting of grouts to cool down to room temperature. The concentration of $12 \mathrm{M}$ of the $\mathrm{NaOH}$ solution was chosen as being adequate to promote the dissolution process from the leaching of alumina and silica [21]. On the other hand, according to Riffai et al. [22], concentration of $\mathrm{NaOH}$ above $14 \mathrm{M}$ can 
cause an excessive delay in the geopolymerization process and consequent long curing time. The composition of sodium silicate solution was as follows: $\mathrm{Na}_{2} \mathrm{O}$ is $24 \%, \mathrm{SiO}_{2}$ is $21 \%$, and distilled water is $55 \%$ by mass. The ratio of sodium silicate to sodium hydroxide was taken as 0.5 . The alkaline solution to silica fume (AS/SF) ratio was taken as 0.5 and 0.8 .

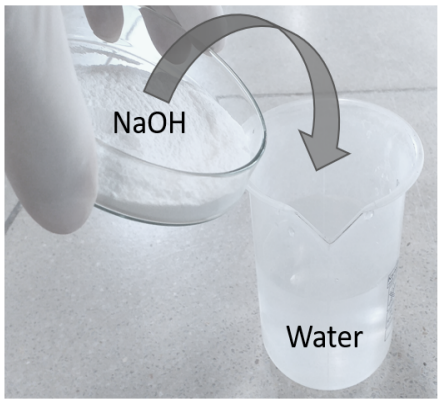

(a)

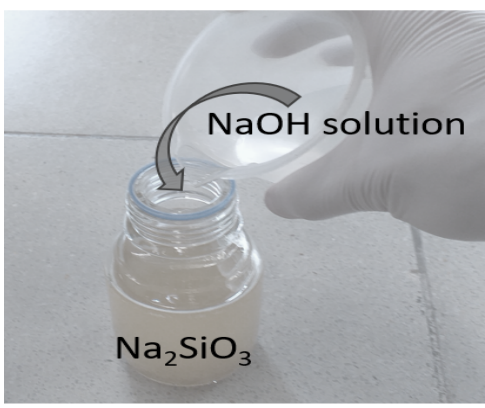

(b)

Figure 1. Preparation of alkaline activator: (a) sodium hydroxide $(\mathrm{NaOH})$ solution; (b) combination of sodium hydroxide $(\mathrm{NaOH})$ and sodium silicate $\left(\mathrm{Na}_{2} \mathrm{SiO}_{3}\right)$.

\subsubsection{Superplasticizer}

To improve the grout fluidity, a polycarboxylate-based superplasticizer (SP) was used. The SP had a specific gravity, chloride content, charge, $\mathrm{pH}$, and solid content of $1.05,<0.10 \%$, anionic, 8 , and $28-32 \%$, respectively. As is widely known, superplasticizers are used to improve the workability of cementitious-based mixtures but their effect on geopolymers has not yet been studied in depth [23-25]. There are even some controversial theories about the contribution of superplasticizers to the properties of geopolymers. Douglas and Brandstetr [24] concluded that the presence of SP causes a reduction in mechanical strength and no improvement in workability was observed. On the other hand, Palacios and Puertas [25] stated that the naphthalene-based SP improves the mechanical strength of slag-based geopolymer pastes and mortars. In this context, the present study also intends to contribute to the knowledge of the influence of superplasticizers on these materials.

\subsection{Grout Preparation}

The grouts were prepared at a room temperature of $26 \pm 4{ }^{\circ} \mathrm{C}$ and a relative humidity of $53 \pm 3 \%$. SF was added to the alkaline solution and mixed using a high shear mechanical mixer for about $3 \mathrm{~min}$. SP was added to the alkali solution before mixing. The mix design details of the grout composition including the SP dosage are presented in Table 2. The reference grout, i.e., NHL-based, was prepared according to the procedure detailed in previous studies $[26,27]$.

Table 2. Grout compositions applied in the study.

\begin{tabular}{cccccc}
\hline & NHL & SF & Water/NHL & AS/SF & SP ${ }^{\mathbf{1}}$ (\%) \\
\hline Ref & $\checkmark$ & - & 0.5 & - & 0.3 \\
GEO_0.5 & - & $\checkmark$ & - & 0.5 & - \\
GEO_0.5_SP & - & $\checkmark$ & - & 0.5 & 0.5 \\
GEO_0.8 & - & $\checkmark$ & - & 0.8 & - \\
GEO_0.8_SP & - & $\checkmark$ & - & 0.8 & 0.5 \\
\hline
\end{tabular}

$1 \%$ of SF or NHL mass as appropriate.

The size of the specimens used in this study was $40 \times 40 \times 160 \mathrm{~mm}^{3}$ (Figure 2a) and for each grout composition, seven specimens were prepared right after the mixing process was completed. The specimens were removed from the mold 15 days after their cast (Figure 2b) and kept at room temperature until the age of testing, which took place at 28 days. Room temperature curing was significantly slower compared to hot curing, which caused a delay in the demolding of specimens [11]. 


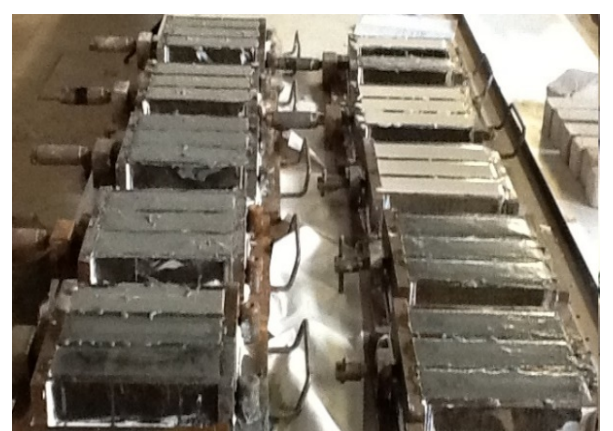

(a)

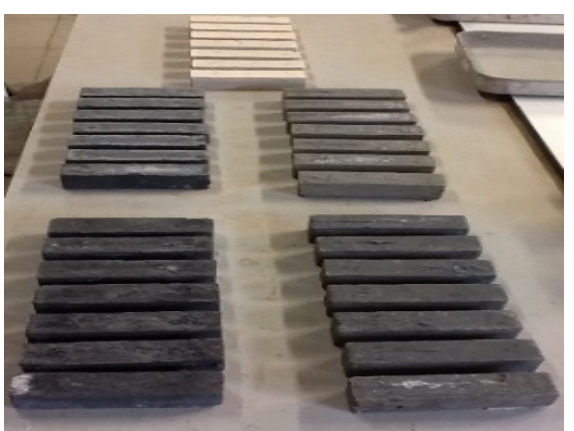

(b)

Figure 2. Preparation of grout specimens: (a) specimen molds after filling with grout; (b) grout specimens after demolding.

\subsection{Test Procedures}

The rheological properties were measured using the Marsh cone test according to ASTM C939-02 [28] and the mini-slump test. The Marsh cone used for this work had a capacity of $1980 \mathrm{ml}$ and an opening with $5 \mathrm{~mm}$ of diameter. A volume of $1000 \mathrm{ml}$ of grout was placed into the cone and the flow time (in seconds) required for $800 \mathrm{ml}$ of grout to flow out was determined. It is well established that the flow time is linked to the grout fluidity, meaning that the longer the flow time, the lower the grout fluidity. In this context, the time needed for the grout to flow can be indexed to its viscosity [29]. The mini-slump test was carried out according to the procedure used in a previous work [30]. After the careful placing of the grout into the mini-cone, to avoid bubbles formation, the cone was vertically lifted and the diameter was measured along the four lines. The final value of spread was an average of three readings. The compressive and flexural strength were determined in accordance with EN 1015-11:1999 [31]. The testing machine Zwick Z050 with $50 \mathrm{kN}$ load cell and deformation rate of $0.7 \mathrm{~mm} / \mathrm{min}$ was adopted. All the values presented were the averages of at least three measurements. The adhesion strength at the interface between grout and a porous support was also studied. The adhesion was analyzed through the flexural tensile test (Figure 3a) using the Zwick Z050 with $50 \mathrm{kN}$ load cell. In the adhesion test, hybrid specimens (see Figure $3 b$ ) made with half grout and half porous support were used. The adopted porous support aims to simulate the absorption characteristics of the materials present in old masonry walls.

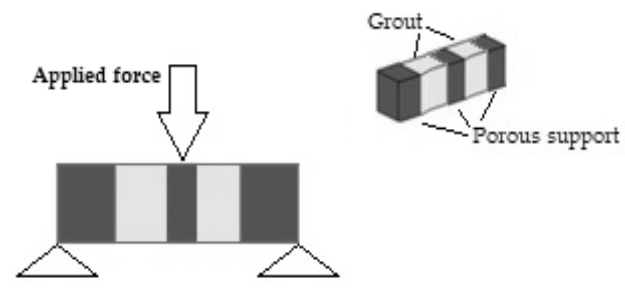

(a)

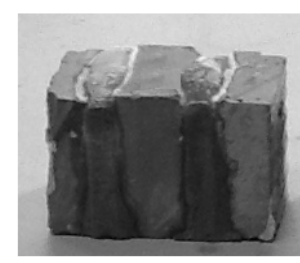

Geopolymer Grout

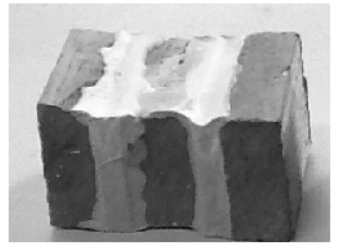

NHL Grout (b)

Figure 3. Adhesion test apparatus: (a) flexural tensile test scheme; (b) illustration of specimens.

\section{Experimental Results and Discussion}

\subsection{Rheological Properties}

It is well established that the spread diameter and flow time evolution are critical rheological parameters in the grout injection, as the grout needs to flow in the masonry channels and cracks until it reaches the voids in the masonry core [18]. Indeed, an understanding and control of the rheology evolution of grout are essential to find out the optimal grout injection technique as well as its strength after hardening. However, the 
rheological measurements of geopolymer materials can be problematic and complex due to the formation of a thick paste as a result of the geopolymerization process and high viscosity of the alkaline solution [32]. The geopolymerization process is highly dependent on the ratio of alkaline solution to precursor, or, in other words, it will determine the speed with which the Si-O-Si bonds start to form and significantly affect the workability of the grout.

As can be seen in Table 3, the studied grouts exhibited spread diameter values ranging between 14.3 and $39.9 \mathrm{~cm}$. An increase in the AS/SF ratio from 0.5 to 0.8 caused an increase in spread diameter of $17.1 \mathrm{~cm}$. Since the grout spread stops when the shear stress becomes lower than the yield stress (yield stress is associated with the minimum stress necessary for grout to start flowing), thereby higher spread means lower yield stress values, which is ideal in injection grouts. This increase is associated with the formation of a less rigid structure, which facilitates the beginning of the grout flow [22].

Table 3. Evolution of rheological parameters as a function of grout composition.

\begin{tabular}{ccc}
\hline & Spread Diameter $(\mathbf{c m})$ & Flow Time (s) \\
\hline Ref & $39.8( \pm 4.0)$ & $5.2( \pm 1.5)$ \\
GEO_0.5 & $14.3( \pm 1.2)$ & $94.1( \pm 5.0)$ \\
GEO_0.5_SP & $25.6( \pm 3.5)$ & $55.3( \pm 3.0)$ \\
GEO_0.8 & $31.4( \pm 1.5)$ & $41.6( \pm 2.0)$ \\
GEO_0.8_SP & $36.5( \pm 2.0)$ & $25.3( \pm 1.8)$ \\
\hline
\end{tabular}

Values in brackets give the standard deviation.

It should also be noted that higher spread values are associated with presence of the SP. This is perhaps explained by the repulsive forces of SP that prevent geopolymerization, which is more noticeable in grouts with AS/SF of 0.5. Concerning the flow time, it showed the same trend as spread diameter. Indeed, the flow time is influenced by both SP and AS/SF ratio and it exhibits a trend where it decreases with their increase. However, according to a previous study, the excessive increase in AS concentration may cause a loss of grout fluidity and such behavior is due to the high viscosity of the AS [33].

The results obtained revealed that geopolymer grouts (at least for the materials and concentrations used), from a rheological point of view, have poor performance compared to the reference grout (Ref), whose rheological properties are considered suitable for injection. Nevertheless, further study is necessary to find the ideal SP concentration that balances fluidity and mechanical strength.

\subsection{Physical and Mechanical Properties}

Hardened density results are shown in Figure 4. The higher hardened density values were obtained for grouts having the highest AS content. Thus, it can be said that they will also be the compositions with the lowest porosity of water absorption by capillarity [34]. As reported before, the geopolymer microstructure is strongly dependent on the alkali and silica fume content. The alkaline concentration accelerated the activation process of geopolymer which led to the formation of reaction products (aluminosilicate gel) that filled the pore microstructure and the open porosity (Figure 5) was reduced [35]. Nevertheless, grouts with the same AS/SF ratio with and without SP showed a slight change in porosity values; it is believed that this is due to the entrained air resulting from the presence of the SP that increases the porosity and compromises the mechanical strength (see Figures 6 and 7). As happens with other binders, the hardened density of geopolymers has a direct effect on its strength. 


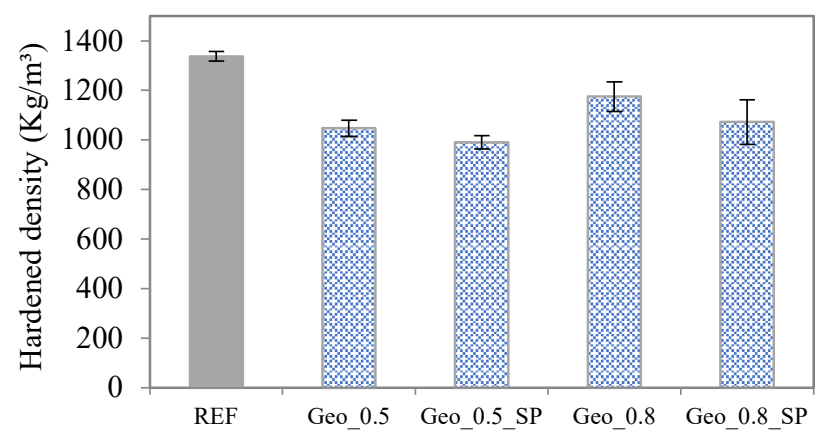

Figure 4. Hardened density of grouts studied.

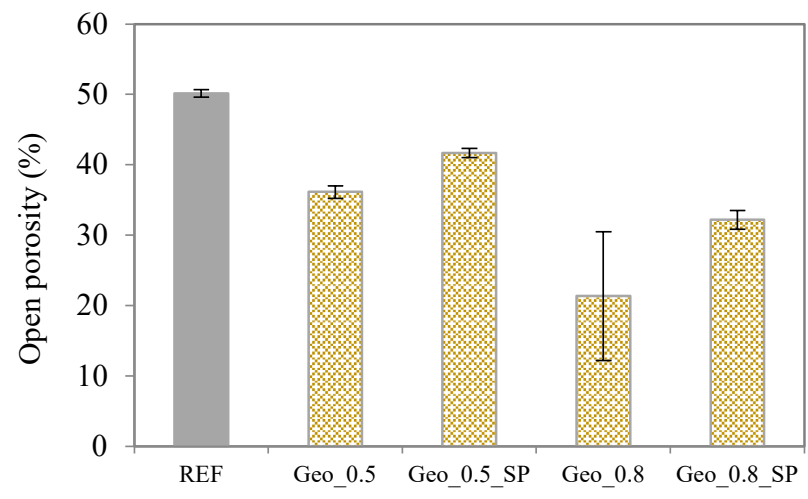

Figure 5. Open porosity of grouts studied.

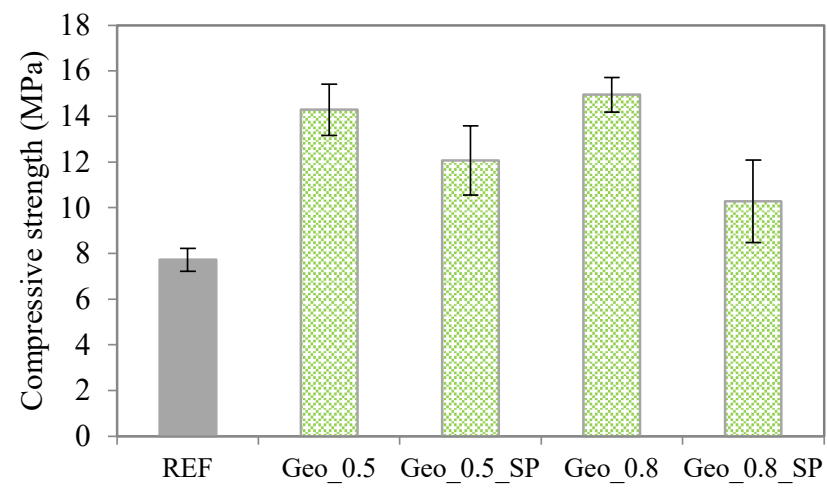

Figure 6. Compressive strength of grouts studied.

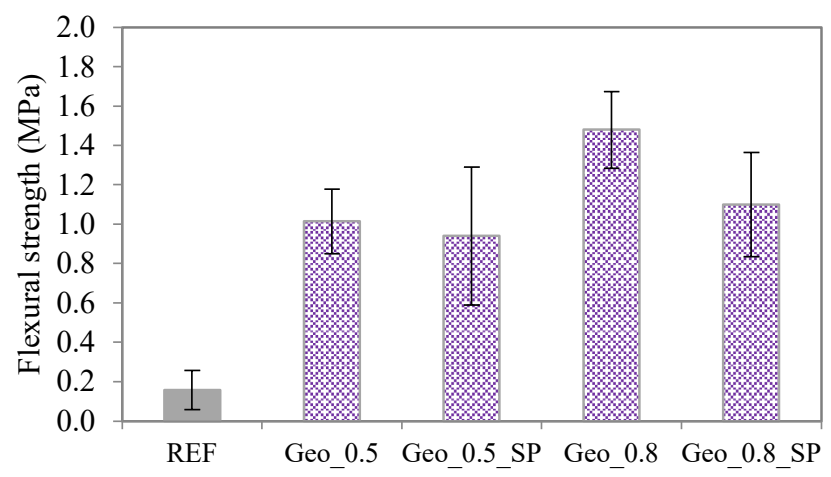

Figure 7. Flexural strength of grouts studied.

Figures 6 and 7 give the flexural and compressive strength of the grouts studied. Flexural strength varies from 0.2 to $1.5 \mathrm{MPa}$, although the compressive strength values 
are in a wide range, varying from 7.7 to $19.0 \mathrm{MPa}$, but not reaching values as high as those obtained by other authors. This behavior can be justified by the fact that curing occurred at room temperature, which caused a delay in the geopolymerization process. The application of heat in grouting operations is not feasible in practical situations; however, in the future, the mixing procedure may have to be modified to take advantage of the heat released from the exothermic reaction during the contact of the alkaline activator with water. From the analysis of previous studies [11,36], it was found that for specimens subjected to curing at room temperature, the resistance at 28 days did not go beyond $10 \mathrm{MPa}$, which is in agreement with the range of values obtained in the present study. Notwithstanding, according to Valluzi et al. [37], who assessed masonry walls through compressive testing before and after grouting operations, it was found that despite the difference in the grout compressive strengths, the strength gains in the walls were similar. This means that the adhesion between masonry elements is preponderant in relation to the mechanical strength of the grout alone.

The results revealed that mechanical properties were reduced in the specimens with SP and with lower AS/SF ratio; such behavior is in agreement with the results obtained by other authors [24,38]. In addition, the movement of alkali and/or water to the surface of the geopolymer causes efflorescence which negatively affects the mechanical performance of the material in regards to external influences [39].

In this study, the evaluation of adhesion strength between the grout and a porous support was assessed, as shown in Figure 8. The results make clear the advantage of geopolymer grouts over NHL-based grouts in terms of improved grout adhesion. There was a $90 \%$ increase in the adhesion of the SF-based geopolymer grout compared to the NHL grout (Ref). If, in terms of compressive strength, the improvements were not significant (it is believed that this is due to the curing conditions), the adhesion strength significantly improves, which is a great benefit from the masonry consolidation point of view. Adhesion is one of the main mechanical requirements in masonry consolidation operations since it is intended to promote connection between the different masonry elements.

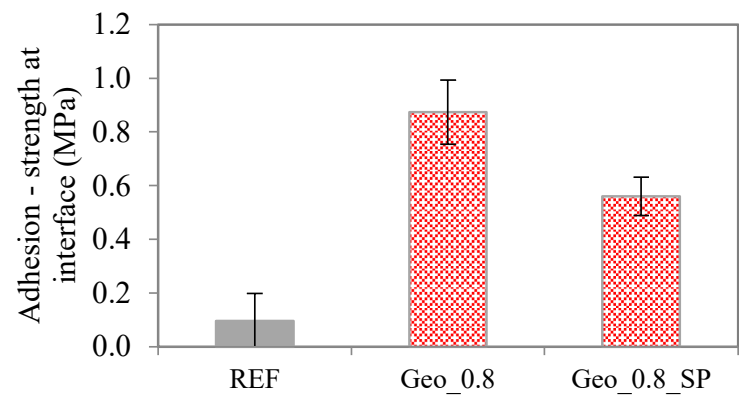

Figure 8. Adhesion strength values at interface between grout and porous support.

The results showed that GEO_0.5 grout exhibited about 30\% higher adhesion strength compared to grout GEO_0.5_SP with SP. This can be explained by higher porosity due to the presence of SP; in other words, the contact area at the grout-support interface is lower, which resulted in reduced adhesion strength.

\section{Conclusions}

A preliminary investigation on fresh and hardened properties of SF-based geopolymer grout for consolidation of old stone masonries has been carried out. The grouts were prepared by mixing SF with an alkaline activator made from $\mathrm{NaOH}$ and $\mathrm{Na}_{2} \mathrm{SiO}_{3}$. The polycarboxylate-based SP was also used to improve the grouts' rheological properties. The main remarks extracted from this study are as follows:

- From a rheological point of view, geopolymer grouts have poor performance compared to the reference NHL-based grout. 
- $\quad$ The presence of SP proved to be beneficial for improving fluidity, which is more noticeable in grouts with AS/SF ratio of 0.5 . The grouts with SP showed an increase in porosity values that may be due in part to the entrained air resulting from the presence of the SP.

- It was found that the increase in the content of AS results in higher spread values which are associated with the formation of a less rigid structure, which facilitates the beginning of the grout flow.

- It was also noticed that higher hardened density values were obtained in the grouts with the AS/SF ratio of 0.8 , which corroborates the theory that geopolymer microstructure is strongly dependent on the alkali content.

- $\quad$ The compressive strength values obtained at 28 days were in the range of 7.7 to 19.0 $\mathrm{MPa}$, but did not reach values as high as those reported in the literature. This is a consequence of room temperature curing, which delayed the geopolymerization.

- There was an increase of about $90 \%$ in the adhesion strength of the geopolymer grout compared to the NHL grout, which is a great benefit. Adhesion is one of the main mechanical requirements in a masonry consolidation intervention.

Finally, it is worth noting that the results are relatively promising and SF-based geopolymer grouts could be a suitable alternative for consolidation of stone masonry buildings. It is clear, however, that further characterization of rheology of this kind of material is needed to overcome the reduced fluidity obtained.

Funding: This work was supported by National Funds through FCT-Portuguese Foundation for Science and Technology under the project UID/CTM/50025 and fellowship with reference SFRH/BPD/108427/2015.

Institutional Review Board Statement: Not applicable.

Informed Consent Statement: Not applicable.

Acknowledgments: Acknowledgements are due to Diana Temporão for assistance in laboratory activities.

Conflicts of Interest: The author declares no conflict of interest.

\section{References}

1. Gartner, E. Industrially interesting approaches to 'low- $\mathrm{CO}_{2}$ ' cements. Cem. Concr. Res. 2004, 34, 1489-1498. [CrossRef]

2. Huang, L.; Krigsvoll, G.; Johansen, F.; Liu, Y.; Zhang, X. Carbon emission of global construction sector. Renew. Sustain. Energy Reviews 2018, 81, 1906-1916. [CrossRef]

3. European Commission. 2050 Long-Term Strategy. Available online: https://ec.europa.eu/clima/policies/strategies/2050_en (accessed on 7 January 2022).

4. Davidovits, J. Geopolymer cement: A review. Geopolym. Sci. Tech. Geopolym. Inst. Libr. 2013, 21, 1-11.

5. Shi, C.; Fernández-Jiménez, A.; Palomo, A. New cements for the 21st century: The pursuit of an alternative to Portland cement. Cem. Concr. Res. 2011, 41, 750-763. [CrossRef]

6. Pagnotta, S.; Tenorio, A.; Tiné, M.; Lezzerini, M. Geopolymers as a potential material for preservation and restoration of Urban Build Heritage: An overview. IOP Conf. Ser. Earth Environ. Sci. 2020, 609, 012057. [CrossRef]

7. Ricciotti, L.; Molino, A.J.; Roviello, V.; Chianese, E.; Cennamo, P.; Roviello, G. Geopolymer Composites for Potential Applications in Cultural Heritage. Environments 2017, 4, 91. [CrossRef]

8. Davidovitz, J. Chemistry and Applications, 2nd ed.; Geopolymer Institute: Saint-quentin, France, 2008.

9. Rangan, V.B. Low-Calcium, Fly Ash-Based Geopolymer Concrete. In Concrete Construction Engineering Handbook; Nawy, E.G., Ed.; CRC Press: Boca Raton, FL, USA, 2008; Chapter 26.

10. Ryu, G.S.; Lee, Y.B.; Koh, K.T.; Chung, Y.S. The mechanical properties of fly ash-based geopolymer concrete with alkaline activators. Constr. Build. Mater. 2013, 47, 409-418. [CrossRef]

11. Saxena, S.K.; Kumar, M.; Singh, N.B. The influence of different alkali solutions on the properties of the pond fly ash-based geopolymer mortar cured at different temperatures and under different conditions. Adv. Cem. Res. 2018, 30, 1-7. [CrossRef]

12. Siyal, A.A.; Azizli, K.A.; Man, Z.; Ullah, H. Effects of parameters on the setting time of fly ash based geopolymers using taguchi method. Procedia Eng. 2016, 148, 302-307. [CrossRef]

13. Hanjitsuwan, S.; Hunpratub, S.; Thongbai, P.; Maensiri, S.; Sata, V.; Chindaprasirt, P. Effects of NaOH concentrations on physical and electrical properties of high calcium fly ash geopolymer paste. Cem. Concr. Compos. 2014, 45, 9-14. [CrossRef] 
14. Clausi, M.; Tarantino, S.C.; Magnani, L.L.; Riccardi, M.P.; Tedeschi, C.; Zema, M. Metakaolin as a precursor of materials for applications in Cultural Heritage: Geopolymer-based mortars with ornamental stone aggregates. Appl. Clay Sci. 2016, 132-133, 589-599. [CrossRef]

15. Pagnotta, S.; Tenorio, A.L.; Tinè, M.R.; Lezzerini, M. Geopolymer mortar: Metakaolin-based recipe for cultural heritage application. In Proceedings of the IMEKO TC-4 International Conference on Metrology for Archaeology and Cultural Heritage, Trento, Italy, 22-24 October 2020; pp. 55-59.

16. Baltazar, L.G.; Henriques, F.M.A.; Temporão, D.; Cidade, M.T. Experimental Assessment of Geopolymer Grouts for Stone Masonry Strengthening. Key Eng. Mater. 2019, 817, 507-513. [CrossRef]

17. Jorne, F.; Henriques, F.M.A.; Baltazar, L.G. Influence of superplasticizer, temperature, resting time and injection pressure on hydraulic lime grout injectability. Correlation analysis between fresh grout parameters and grout injectability. J. Build. Eng. 2015, 4, 140-151. [CrossRef]

18. Baltazar, L.G.; Henriques, F.M.A.; Cidade, M.T. Rheology of natural hydraulic lime grouts for conservation of stone masonry influence of compositional and processing parameters. Fluids 2019, 4, 13. [CrossRef]

19. CEN. EN459-1:2010; Building Lime. Part 1: Definitions, Specifications and Conformity Criteria; CEN: Brussels, Belgium, 2010.

20. Phoo-ngernkham, T.; Maegawa, A.; Mishima, N.; Hatanaka, S.; Chindaprasirt, P. Effects of sodium hydroxide and sodium silicate solutions on compressive and shear bond strengths of FA-GBFS geopolymer. Constr. Build. Mater. 2015, 91, 1-8. [CrossRef]

21. Abdullah, A.; Hussin, K.; Abdullah, M.M.A.B.; Yahya, Z.; Sochacki, W.; Razak, R.A.; Błoch, K.; Fansuri, H. Article the effects of various concentrations of $\mathrm{NaOH}$ on the inter-particle gelation of a fly ash geopolymer aggregate. Materials 2021, $14,1111$. [CrossRef]

22. Rifaai, Y.; Yahia, A.; Mostafa, A.; Aggoun, S.; Kadri, E.H. Rheology of fly ash-based geopolymer: Effect of NaOH concentration. Constr. Build. Mater. 2019, 223, 583-594. [CrossRef]

23. Jang, J.G.; Lee, N.K.; Lee, H.K. Fresh and hardened properties of alkali-activated fly ash/slag pastes with superplasticizers. Constr. Build. Mater 2014, 50, 169-176. [CrossRef]

24. Douglas, E.; Brandstetr, J. A preliminary study on the alkali activation of ground granulated blast-furnace slag. Cem. Concr. Res. 1990, 20, 746-756. [CrossRef]

25. Palacios, M.; Puertas, F. Effect of superplasticizer and shrinkage-reducing admixtures on alkali-activated slag pastes and mortars. Cem. Concr. Res. 2005, 35, 1358-1367. [CrossRef]

26. Baltazar, L.G.; Henriques, F.M.A.; Cidade, M.T. Grouts with improved durability for masonry consolidation: An experimental study with non-standard specimens. Key Eng. Mater. 2017, 747, 480-487. [CrossRef]

27. Baltazar, L.G.; Henriques, F.M.A.; Douglas, R.; Cidade, M.T. Experimental characterization of injection grouts incorporating hydrophobic silica fume. J. Mater. Civ. Eng. 2017, 29, 04017167. [CrossRef]

28. ASTM C939-02. Standard Test Method for Flow of Grout for Preplaced-Aggregate Concrete (Flow Cone Method). Available online: https:/ / www.astm.org/c0939_c0939m-16a.html (accessed on 8 November 2021).

29. Baltazar, L.G.; Henriques, F.M.A. Rheology of grouts for masonry injection. Key Eng. Mater. 2015, 624, 283-290. [CrossRef]

30. Baltazar, L.G.; Henriques, F.M.A.; Cidade, M.T. Experimental study and modeling of rheological and mechanical properties of NHL grouts. J. Mater. Civ. Eng. 2015, 27, 04015055. [CrossRef]

31. EN 1015-11:1999; Methods of Test for Mortars for Masonry-Part 11: Determination of Flexural and Compressive Strength of Hardened Mortar; CEN, European Committee for Standardization, 1999. Available online: https://standards.iteh.ai/catalog/ standards/cen/14596d4c-119b-4a78-94e1-3fe481a29bde/en-1015-11-2019(accessed on 8 November 2021).

32. Provis, J.L. Activating solution chemistry for geopolymers. Geopolym. Struct. Process. Prop. Ind. Appl. 2009, 50-71. [CrossRef]

33. Favier, A.; Hot, J.; Habert, G.; Roussel, N.; d'Espinose de Lacaillerie, J.-B. Flow properties of MK-based geopolymer pastes. A comparative study with standard Portland cement pastes. Soft Matter 2014, 10, 1134-1141. [CrossRef] [PubMed]

34. Ma, Y.; Hu, J.; Ye, G. The pore structure and permeability of alkali activated fly ash. Fuel 2013, 104, 771-780. [CrossRef]

35. Provis, J.L.; Myers, R.J.; White, C.E.; Rose, V.; van Deventer, J.S.J. X-ray microtomography shows pore structure and tortuosity in alkali-activated binders. Cem. Concr. Res. 2012, 42, 855-864. [CrossRef]

36. Suwan, T.; Fan, M. Effect of manufacturing process on the mechanisms and mechanical properties of fly ash-based geopolymer in ambient curing temperature. Mater. Manuf. Process. 2017, 32, 461-467. [CrossRef]

37. Valluzzi, M.R.; Porto, F.; Modena, C. Behavior and modeling of strengthened three-leaf stone masonry walls. Mater. Struct. 2004, 37, 184-192. [CrossRef]

38. Bashar, I.I.; Alengaram, U.J.; Jumaat, M.Z.; Islam, A. The effect of variation of molarity of alkali activator and fine aggregate content on the compressive strength of the fly ash: Palm oil fuel ash based geopolymer mortar. Adv. Mater. Sci. Eng. 2014, 2014, 245473. [CrossRef]

39. Criado, M.; Fernandez-Jimenez, A.; de la Torre, A.G.; Aranda, M.A.G.; Palomo, A. An XRD study of the effect of the $\mathrm{SiO}_{2} / \mathrm{Na}_{2} \mathrm{O}$ ratio on the alkali activation of fly ash. Cem. Concr. Res. 2007, 37, 671-679. [CrossRef] 